\title{
Editorial
}

\section{Pancreatic Surgery: Past, Present, and Future}

\section{Calogero lacono}

Department of Surgery, Unit of Hepato-Pancreatico-Biliary Surgery, University of Verona Medical School, Verona, Italy

The original idea to publish a monographic issue on the pancreatic surgery came from Prof. Nikolaos Lygidakis, the former Secretary General of International Association of Surgeons, Gastroenterologists and Oncologist (IASGO). After his sudden passing in February 2015, Prof. Kyoichi Takaori succeeded the position of Secretary General and engaged in all activities of IASGO including the editorship of official journals. In order to keep up the legacy of Prof. Lygidakis, Prof. Takaori suggested that I collect manuscripts for a monographic issue entitled 'Pancreatic surgery: Past, Present and Future'. With tremendous efforts from the executive members, that is, IASGO President Prof. Masatoshi Makuuchi, Secretary Generals Prof. Takaori and Prof. Dan Duda, IASGO Editor-in-Chief Prof. Guido Torzilli and others, 'Digestive Surgery' became the official journal of IASGO and we sought to publish this monographic issue. Accordingly, we invited several colleagues and friends from the association who had high expertise in pancreatic surgery to collaborate on this project. For the purpose of presenting an exhaustive picture of the current topics in pancreatic surgery, we sought to include expert opinions of colleagues throughout the world. After a collegial discussion for this issue, we reviewed and included 3 original works, 2 How I Do It articles and 8 reviews from Europe (France, Germany, Italy, Spain, Hungary, Sweden, Switzerland) as well as from prestigious centers in the United States (Johns Hopkins Hospital, Massachusetts General Hospital, Mayo Clinic) and Japan (Kyoto University, Nagoya Central Hospital) in order to provide answers relating to select topics of high clinical interest.

In the first manuscript from the Mayo Clinic, Ahmed et al. [1] analyzed the effect of the definition of fluid collection in the management of acute pancreatitis, proposed by the Atlanta classification 2013. Angiolini et al. [2] from the IRCCS Istituto Clinico Humanitas of Milano described the role of C-reactive protein to predict the occurrence of surgical site infection (SSI) following pancreaticoduodenectomy. Despite SSI usually being a low grade complication, it has been associated with an increased length of stay and readmission rate following pancreatic surgery.

Four papers, 2 original papers and 2 reviews are focused on outcomes after the minimally invasive pancreatic surgery (MIS). Alsfasser et al. [3] from Rostock, Germany, presented a review on usefulness and limitations of minimally invasive approach while Nappo et al. [4] questioned whether MIS is really the future, particularly in the oncological surgical field. Fernández-Cruz et al. [5] analyzed the MIS for large distal pancreatic masses and Napoli et al. [6] described the learning curve for the robotics-assisted pancreaticoduodenectomy.

\section{KARGER}

E-Mail karger@karger.com

www.karger.com/dsu
C 2016 S. Karger AG, Basel

0253-4886/16/0334-0257\$39.50/0
Prof. Calogero Iacono, MD

Department of Surgery, Unit of Hepato-Biliary-Pancreatic Surgery

University of Verona Medical School, 'GB Rossi' University Hospital

P.le L.A. Scuro, 10, IT-37134 Verona (Italy)

E-Mail Calogero.Iacono@univr.it 
An additional 2 How I Do It papers presented a detailed description of surgical technique variation (or approaches). While the artery-first approaches to a pancreaticoduodenectomy have been recently highlighted in Europe, the original concept of approaching the mesenteric vessels was first described by Nakao [7]. Furthermore, in the quest of more oncologic resection, Takaori et al. [8] extended the artery-first approaches to a distal pancreatectomy. These surgical techniques were precisely described with intraoperative pictures in this issue. In order to decrease the occurrence of pancreatic leak, Kollár et al. [9] extensively analyzed several possible management of the pancreatic stump following a distal pancreatectomy.
Two different reviews discussed the role of total pancreatectomy questioning the true indication in the general setting today (Andrén-Sandberg et al. [10]) and specifically as treatment of IPMN (Griffin et al. [11]).

This monographic issue was concluded by 2 papers regarding the management of locally advanced pancreatic ductal adenocarcinoma (PDAC). Loehrer and Ferrone [12] from the MGH group reviewed all the different treatments while Linecker et al. [13] focused on the ablation strategies for the locally advanced PDAC.

I thank all the authors who have collaborated on this project and for sharing their experience on pancreatic surgery.

Calogero Iacono, Verona, Italy

\section{References}

$>1$ Ahmed A, Gibreel W, Sarr MG: Recognition and importance of new definitions of peripancreatic fluid collection in managing patients with acute pancreatitis. Dig Surg 2016; 33:259-266.

-2 Angiolini MR, Gavazzi F, Ridolfi C, Moro M, Morelli P, Montorsi M, Zerbi A: Role of Creactive protein assessment as early predictor of surgical site infections development after pancreaticoduodenectomy. Dig Surg 2016; 33:267-275.

3 Alsfasser G, Hermeneit S, Rau BM, Klar E: Minimally invasive surgery for pancreatic disease - current status. Dig Surg 2016;33:276283
4 Nappo G, Perinel J, El Bechwaty M, Adham M: Minimally-invasive pancreatic resection: is it really the future? Dig Surg 2016;33:284289.

$\checkmark 5$ Fernández-Cruz L, Poves I, Pelegrina A, Burdío F, Sánchez-Cabus S, Grande L: Laparoscopic distal pancreatectomy for pancreatic tumors: does size matter? Dig Surg 2016;33: 290-298.

6 Napoli N, Kauffmann EF, Palmeri M, Miccoli M, Costa F, Vistoli F, AmoreseG, Boggi $\mathrm{U}$ : The learning curve in robotic pancreaticoduodenectomy. Dig Surg 2016;33:299-307.

7 Nakao A: The mesenteric approach in pancreatoduodenectomy. Dig Surg 2016;33:308313.

-8 Takaori K, Uemoto S: Artery-first distal pancreatectomy. Dig Surg 2016;33:314-319.
$>9$ Kollár D, Huszár T, Pohárnok Z, Cselovszky E, Oláh A: A review of techniques for closure of the pancreatic remnant following distal pancreatectomy. Dig Surg 2016;33:320-328.

10 Andrén-Sandberg A, Ansorge C, Yadav TD: Are there indications for total pancreatectomy in 2016? Dig Surg 2016;33:329-334.

11 Griffin JF, Poruk KE, Wolfgang CL: Is it time to expand the role of total pancreatectomy for IPMN? Dig Surg 2016;33:335-342.

12 Loehrer AP, Ferrone CR: Treatment of locally advanced pancreatic ductal adenocarcinoma. Dig Surg 2016;33:343-350.

13 Linecker M, Pfammatter T, Kambakamba P, DeOliveira ML: Ablation strategies for locally advanced pancreatic cancer. Dig Surg 2016; 33:351-359. 